\title{
Socio-Economic Up-Liftment through Milk Production in Bihar, India
}

\author{
Rakesh Kumar $^{1 *}$ and Rahul Kumar ${ }^{2}$ \\ ${ }^{1}$ School of Ecology and Environmental Studies, Nalanda University, Rajgir, India \\ ${ }^{2}$ Sanjay Gandhi Institute of Dairy Technology, Bihar Animal Sciences University, Patna, India \\ *Corresponding author
}

A B S T R A C T

\begin{tabular}{|l|}
\hline Ke y w o r d s \\
$\begin{array}{l}\text { Milk production, Co- } \\
\text { operatives, Employment, } \\
\text { Rural areas, Social- } \\
\text { economical }\end{array}$ \\
\hline Article Info \\
\hline $\begin{array}{l}\text { Accepted: } \\
\text { 10 April } 2018 \\
\text { Available Online: } \\
\text { 10 May } 2018\end{array}$ \\
\hline
\end{tabular}

The co-operative system is aimed to provide employment and services in the society with the participation and inter-dependency of humanity work and the markets. It creates a wave of self -employment to millions of people either in rural areas or urban areas. Therefore, the milk production by co-operatives generated secondary income other than agriculture for the rural people and aimed to alleviate poverty and unemployment in the rural or countryside areas. The decrease in the production of agricultural products and uncertainty of crops survival due to change in local weather pattern as well as the price of products seek a challenge for farmers to increase their income. A large number of population is getting benefits for their family from the nutritional point of view, alternative source of regular income and employment and service together and other support from the federation to increase the milk production as well as animal health. Moreover, the social differences got reduced as people from a different form of society come under a roof for the common purpose, although they belong to a different caste, gender, age or income.

\section{Introduction}

Rural India faces a great deal of hardship to own a day's meal. A larger percentage of rural people in India involved in farming, animal husbandry, and different appurtenant activities. Today, agricultural income has been diminished. The marginal and small farmers were not capable of achieving profits from crop cultivation. Further, cattle farming emerge as an enterprise for an alternative source of income (Singh and Joshi, 2008). Since rural are less literate and possess restricted skills, in the meantime the hunt for alternate financial gain is pushed to do jobs.
Consequently, more of them taken for cattle farming, i.e., the rearing and selling of milk as an alternative source of income. In India, the income from dairy sector is recorded highest. It was shown that the total income was increased by $87.51 \%$ (Rais et al., 2007). The dairy enterprise has the potential for providing ample work opportunities for those classes of which people are either uneducated or with limited skills. This sector showed the cooperative society as a potent tool to ameliorate the economic and social change in the rural regions of the state which would be a positive outcome for the alleviation of poverty from the countryside (Punjrath, 1989). The 
governing body of the dairy farm had a positive impact on the socio-economic condition of farmers (Thakur et al., 1989).

\section{Concept of co-operatives - Anand pattern}

International Co-operative Alliance (ICA, 2009) noted that the cooperative model is the key element for the social as well as economic development in both growing and developed countries as well. The Anand Pattern is three tiers integrated cooperative structure which works at Village Society, the District Union, and the State Federation. Maximizing farmer profit and productivity through cooperative effort is the authentication of the Anand Pattern. A fellowship which was started with the financial backing of a couple of farmers with a commission to prevent the exploitation by middlemen bit by bit became the largest brand within the commonwealth. The brand, 'Amul -The style of India' that not solely modified the lives of the many poor farmers however conjointly took our nation to new heights. Dr. Verghese Kurien created the Amul corporative, who is additionally referred to as the "Father of the White Revolution" in India (Fig. 1).

The producer's share in consumer's rupee (Ps) for marketing chains was calculated using the equation (Singh et al., 2012):

$\mathrm{P}_{\mathrm{S}}=\frac{\mathrm{pf}}{\mathrm{P}_{\mathrm{c}}} \mathrm{X} 100$

Where $\mathrm{P}_{\mathrm{S}}$ is the producer's share in consumer's rupee; $\mathrm{P}_{\mathrm{F}}$ is the price received by milk producer, and $\mathrm{P}_{\mathrm{C}}$ is the price paid by the consumer.

The milk production increases by $19 \%$ in the last three years which crosses above 163.6 million tones milk in India, leading to a significant increase in dairy farmers' income. The dairy market in India is expected to continue growing at a rate of over $15 \%$, over the next five years, mostly due to a growth in the consumption of value-added products such as cheese, curd, flavored milk, etc. In order to meet the demand of the milk in the market leads to the growth of the dairy industry, a sustainable and robust dairy farming sector requires being developed. It is currently established by a marginalized farmer who has two animals and uses the dairy income to supplement his/her agriculture income.

\section{Social impact}

The White Revolution movement in the villages contributed changes to the society dramatically. The cooperative of the milk production is perceived as a means of livelihood in the society which breaks down the divisions of social as well as economic discrimination. Caste barriers are gradually eroding in equalizing the progression in prior to the milk collection center. Untouchables could not have even dreamt of commercialism milk for common use in the traditional societies. Non-schooling education has been spreading in the society, i.e., the animal health care, cattle balance diet, and insemination centers which are providing health, nutrition, and sex education.

In rural India, the role of women was confined in the house, but the cooperative movement changes the position of adult females. The women are playing a prevalent role in different agricultural activities, and their involvement in dairy cattle is much higher than others, i.e., an extent of almost $95 \%$ (Sardana, 1988). The development of rural women and their participation plays a substantial role in socio-economic development of the state (Ramananda and Kumar, 2010). The dairy development is contributing an improvement in the nutritional and economic status of the people in a rural location (Bowonder et al., 1987). The 
upliftment of women in the society is an essential ingredient of human development, has been considered as the core of the sustainable development of the nation (Chaudhary and Sharma, 2008) (Table 1).

\section{Economic role of dairy farming}

Milk as human food - The protein need of man is mainly by milk. The deficiency of protein in India leads to malnutrition and poorer health of Indian men and women, who lack in average stamina. Milk is the wholesome food, balanced in protein, fat, carbohydrates, vitamin and mineral.

As draught animal - Cattle are used in many ways to agriculture, particularly as a draught animal, drawing the ploughs and carts, taking the load. The bullock power provides the motive power to the Indian agricultural and allied activities. About 80 million of working animal provides about 40 million of electrical energy equivalent power the rural sector of agricultural activities.

Manure - The cow dung and urine have been used as valuable manure in farms. Their pens are used by farmers, on payment, for fertilizing the vacant land during the off session.

Energy Resource - The dung is a source of energy which is equivalent to Rs.43.47 billion annually. It is used for extracting biogas and well-digested manure at the same time, and also killing the seed and weeds.

Ready and steady money for farmers - The milk and its products, the calves are ready money for farmers whenever they need to buy input for the farming or for paying the physician or buying other household articles. The agricultural income is seasonal, but the milch income and income from the sale of animals is continuous, spread over the year. Even if the animal dies, the carcasses are eaten as food, and the skin /hide is sold.

Alter net source of living - It is a fact of life, that when agriculture fails due to vagaries of nature, particularly in dry tracts, dairy farming comes in handy for the farmers to tide over the adversity. Often it so happens that landless take up the job of rearing calves.

Employment - Animal husbandry is a great source of employment for the rural folk, both to the laborers and small landowners. They keep cattle in the backyard, to breed and serve as food for themselves or sale in the market (Table 2-6).

\section{Cattle manure as fertilizer}

Cattle dung or manure is the waste product of bovine animal species. These species include domestic cattle buffalo, yak, and water buffalo. The dung is the undigested residue of plant matter which has passed through the animal's gut. The composition of manure differs from fresh or composted manure. It also varies with the type of cattle, age, the composition of feed, rations, climate, type of bedding, manure storage and manure handling. The cattle manure application to farmland is an economical and environmentally sustainable mechanism for increasing crop production. Nutrients in cattle manure can replace commercial fertilizers. The plants require nutrient for their growth and all nutrient be present in cattle manure. Such type of manure is capable of reducing the dependency of farmers on the commercial nutrients. However, the nutrient composition of manure varies considerably. In the cattle manure, the concentration of nutrients are low in comparison to commercial nutrients, that is why cattle manure require high application rates equivalent to a concentration of commercial nutrients. Cattle manure has nutrients either in the inorganic or the organic form. 
Table.1 Small dairy farm can be started with two cows of advanced breed (Under Samagra Gavya Vikas Yojana 2017-18)

\begin{tabular}{l|l|l} 
Basic & Advanced breed of each milch cattle will give 3500 litres of millk over a \\
period of 300 days after giving birth of calf. Each animal will be in dry \\
period of 65 days. Animal will be of first or second calving.
\end{tabular}

\section{Technical parameter:-}

Total number of cattle in one unit2

Each cattle daily average milk production-

12 litres

3 Daily Required feed per cattle

1) During milking

2) During dry period

\begin{tabular}{|l|c|}
\hline Green fodder & $20 \mathrm{Kg}$ \\
\hline Dry feed & $5 \mathrm{Kg}$ \\
\hline Balanced animal feed & $5 \mathrm{Kg}$ \\
\hline Green fodder & $15 \mathrm{Kg}$ \\
\hline Dry feed & $7 \mathrm{Kg}$ \\
\hline Balanced animal feed & $1 \mathrm{Kg}$ \\
\hline
\end{tabular}

4 Financial criteria

Price of an improved breed of cattle

Rs. 50,000

Per litre of milk sale price

Rs. 35

Price of balanced animal feed per $\mathrm{kg}$

Rs. 20

Price of green fodder per $\mathrm{kg}$

Rs. 3

Price of dry feed per kg

Rs. 5

Expenditure on Maintenance and animal treatment of cattle per unit

Rs. 2,500

Income from sale of each gunny bag

Rs. 20

Table.2 Capital expenditure

\begin{tabular}{|l|l|l|c|}
\hline 1 & Milch animal-02 & $\begin{array}{l}\text { At the rate of Rs.5000 per milch cattle } \\
(2 \times 50000)\end{array}$ & Rs.1,00,000 \\
\hline 2 & Cattle insurance & $\begin{array}{l}\text { At the rate of } 6 \% \text { of purchase price } \\
(100000 \times 6 \%)\end{array}$ & Rs.6,000 \\
\hline
\end{tabular}

Table.3 Per year fodder and grain required for animals adult assessment is given below

\begin{tabular}{|l|l|c|c|}
\hline No. & Detail of animals & Number & Adult unit \\
\hline $\mathbf{1}$ & Milch animals & 2 & 2 \\
\hline 2 & Male/female calf & 2 & 1 \\
\hline Total & $\mathbf{4}$ & $\mathbf{3}$ \\
\hline
\end{tabular}


Table.4 In one year cost and requirement of green fodder, dry feed, and balanced animal feed

\begin{tabular}{|c|c|c|c|}
\hline No. & Quantity & Rate & Price \\
\hline 1 & $\begin{array}{l}\text { Dry feed } \\
\text { i) Daily } 5 \mathrm{~kg} \text { per adult unit for } 300 \text { days milking } \\
\text { period } \\
(5 \times 3 \times 300)=45 \text { quintal } \\
\text { ii) Daily } 7 \mathrm{~kg} \text { per adult unit for } 65 \text { days dry period } \\
(7 \mathrm{X} 3 \mathrm{X} 65)=13.65 \text { quintal } \\
\text { i+ii= } 58.65 \text { quintal }=59 \text { quintal }\end{array}$ & $\begin{array}{l}\text { Rs. } 500 \text { per } \\
\text { quintal }\end{array}$ & Rs. 29,500 \\
\hline 2 & $\begin{array}{l}\text { Green fodder } \\
\text { i) Daily } 20 \mathrm{~kg} \text { per adult unit for } 300 \text { days milking } \\
\text { period } \\
(20 \times 3 \times 300)=180 \text { quintal } \\
\text { ii) Daily } 15 \mathrm{~kg} \text { per adult unit for } 65 \text { days dry } \\
\text { period } \\
(15 \times 3 \times 65)=29.25 \text { quintal } \\
\text { i+ii=209.25quintal = } 210 \text { quintal }\end{array}$ & $\begin{array}{l}\text { Rs. } 300 \text { per } \\
\text { quintal }\end{array}$ & Rs. 63,000 \\
\hline 3 & $\begin{array}{l}\text { Balanced animal feed } \\
\text { i) Daily } 5 \mathrm{~kg} \text { per adult unit for } 300 \text { days milking } \\
\text { period } \\
(5 \times 2 \times 300)=30 \text { quintal } \\
\text { ii) Daily } 1 \mathrm{~kg} \text { per adult unit for } 65 \text { days dry period } \\
(1 \times 2 \times 65)=1.30 \text { quintal } \\
\text { iii }) \quad \text { Daily } 0.50 \mathrm{~kg} \text { per calf unit for } 365 \text { days }(0.5 \mathrm{X} \\
2 \times 365)=3.65 \text { quintal } \\
\text { i+ii+iii }=34.95 \text { quintal }=35 \text { quintal }\end{array}$ & $\begin{array}{l}\text { Rs. } 2,000 \text { per } \\
\text { quintal }\end{array}$ & Rs. 70,000 \\
\hline \multicolumn{3}{|c|}{$\operatorname{Total}(1+2+3)$} & Rs.1,62,500 \\
\hline
\end{tabular}

Table.5 Income and expense

\section{Income}

1 Total produced milk 7000 litres, worth 35 per litre(35 X 7000)

2 Sell of femalecalf, per female calf cost Rs.26000

3 Sell of malecalf per male calf cost Rs.8000

4 Sell of gunny bag(70 X 20)

Total sum

\section{Expense}

\section{Expenditure on fodder and grain}

2 Spending on animal insurance (6\%) each year

3 Expenditure on Maintenance and treatment of cattle

Total sum

Profit $=$ Income-expense $=2,80,400-1,71,000=1,09,400$

In this way, Dairy farming of 2 advanced cattle breed benefit Rs.1, 09,400 
Table.6 Nutrient concentration in cattle manure and commercial fertilizer

\begin{tabular}{|l|c|c|}
\hline & Solid Manure (Lb/tonne) & Commercial Fertilizer (Lb./tonne) \\
\hline Nitrogen (N) & $7-36$ & 1030 \\
\hline Phosphorus (P) & $2-6$ & 500 \\
\hline Potassium (K) & $7-17$ & 1160 \\
\hline Sulphur (S) & $0.1-3$ & 540 \\
\hline
\end{tabular}

Note: multiply $\mathrm{P}$ by 2.3 to get $\mathrm{P}_{2} \mathrm{O}_{5}$ and $\mathrm{K}$ by 1.2 to get $\mathrm{K}_{2} \mathrm{O}$

(Source: www.soilcc.ca/ggmp_fact_sheets/pdf/Cattle\%20manure.pdf)

Fig.1 Flow of capital and milk- Anand Concept

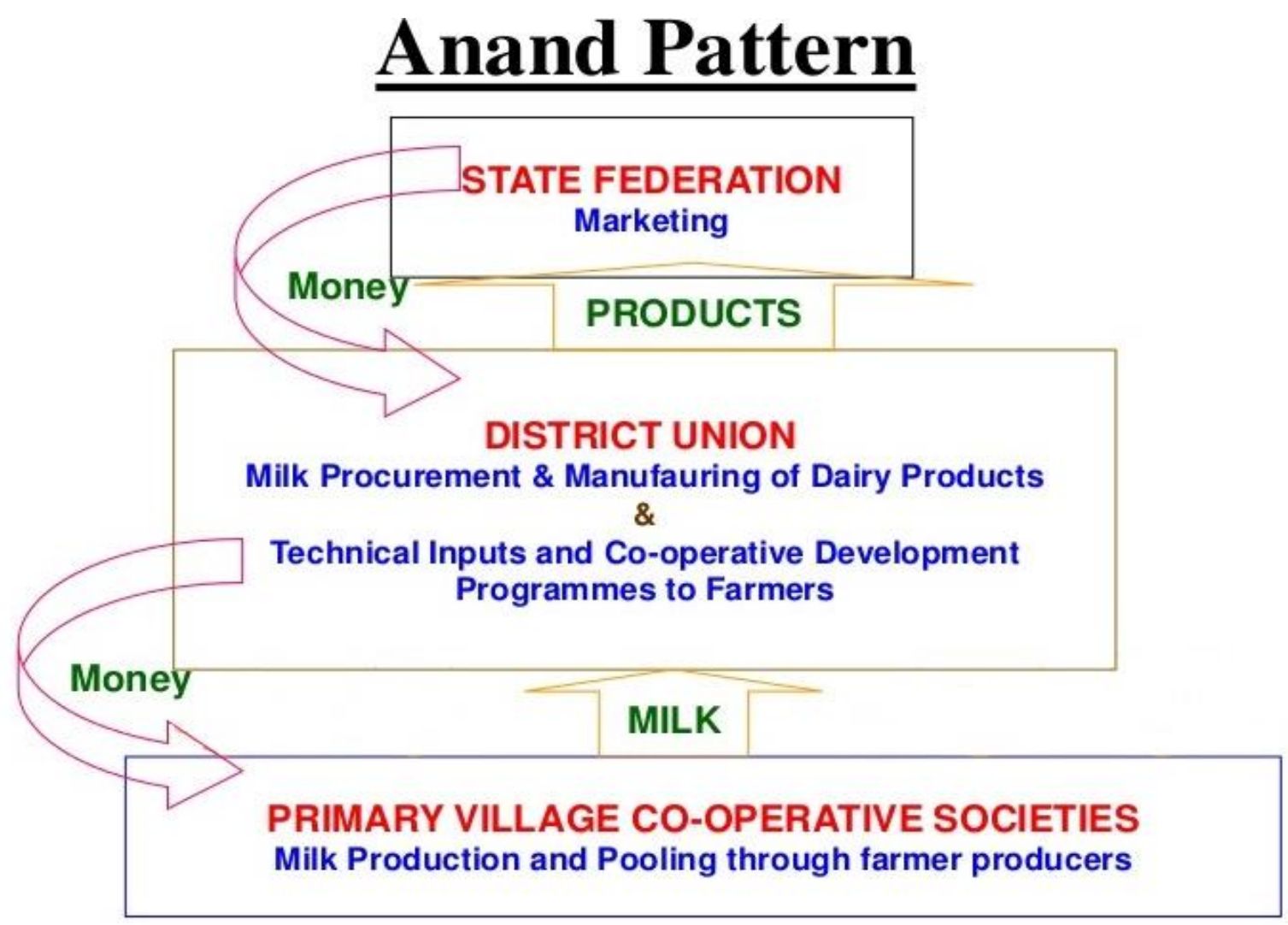

\section{Sustainable production of Milk}

To achieve sustainable production of milk, the future direction of the dairy industry concern about welfare, nutrition, and health of animal and society. Agriculture has the challenge of providing the food security to meet the global population in such a way that it can be achieved in both environmentally and socially acceptable at the same time to maintain economic viability.
Some dairy farm is working on the production of milk at economic scale while other at small farms, like on the pasture-based farm and less dependent on chemical and pharmaceutical inputs in comparison to a large farm. Growing technological facilities expanded the massive production of milk to meet demands of more population. There are different management systems have an impact on both cows as individual and dairy enterprise as a whole. So, the concept of sustainability covers whole 
system, i.e., feeding or health of cows, their offspring, and the environment of grazing field or forage production, soil quality, and different feed resources.

\section{Two-axis milk pricing policy}

Liquid milk plants have a differential pricing system for flush and lean months based on the fat and SNF content of milk, with provision for the payment of a premium for a higher fat and SNF content than the specified standard (ICAR). According to this pricing policy, the calculation of milk's price by fixing the rate of fat and SNF priory. The "two-axis milk pricing" system discourages adulteration of milk and provides a common pricing approach to both cow and buffalo milk. The requirement by Food Safety and Standards Rules (FSSR) - 2011 (erstwhile PFA) for cow milk is $3.0 \%-4.0 \%$ fat and $8.5 \%-9.0 \%$ SNF while those for buffalo milk 5.0\%-6.0\% fat and minimum 9.0\% SNF (ICAR, n.d.) throughout the country. This is done with a view to encouraging the milk production through crossbreeds as well as high-yielding indigenous milch animals to give adequate incentive for the production of milk. In the context of pricing policy, National Dairy Development Board (NDDB) has suggested the 'two-axes milk pricing' policy implementation in the country. India has been producing large quantities of buffalo milk when compared with any other country. Buffalo milk is being rich in fat content always attracted good price in comparison to cow milk.

The study showed that the cost of milk was maximum for the local cow followed by buffalo and crossbred cow (Badal and Dhaka, 1998). Keeping the socio-economic characteristics in view about the above aspects, Pawar and Pawar (2010) stated that the consumer preferred to pay a high price for buffalo's milk. Therefore, farmers are directly selling buffalo's milk to the consumers to get more benefits, and the cow milk is sold to the cooperative's dairy.

In Bihar, milk production accounting about 2.9 MT, about $3.28 \%$ of the total milk production in the country. However, COMPFED, Patna are processing only 9-10 $\%$ of milk production and only $2-3 \%$ in the private sector. There are eight co-operative milk unions in the state of Bihar along with three major diary projects, like Nalanda Dairy Project, Koshi Dairy Project and Magadh Dairy Project and have total 66.45 lakh litre per day milk processing capacity and they procure 44.56 LLPD milk. According to Report no. 44 of an agro-economic research centre for Bihar and Jharkhand 2017, the distribution of social groups of milk producers among DCS or Non-DCS. Therefore, the majority were found from OBCs (56.67\%), General (30.83\%), and Scheduled Caste (12.50\%) Whereas, in NonDCS, $62.50 \%$ was OBCs followed by General $(25 \%)$ and SC $(12.50 \%)$. The yield of the milch animal in Bihar was found to be extremely low. Therefore, the state department of animal husbandry and dairy play a crucial role to raise milk production along with the awareness to adopt the scale of dairy farming and animal health care.

\section{References}

Badal, P.S., and Dhaka, J.P. 1998. An analysis of feeding pattern and cost of milk production in Gopalganj district of Bihar, Indian J. Dairy, Sci., 51(2): 212215.

Bowonder, B., Dasgupta, B., Gupta, S. and Prasad, S.S.R. 1987. Further evidence on the impact of dairy development programme. Economic and Political Weekly, 22(13): A6-A15.

Chaudhary and Sharma 2008. shodhganga.inflibnet.ac.in. 
ICA 2009. Retrieved April 6, 2018, from www.ica.coop.

ICAR. (n.d.) ICAR e-course. Retrieved from Market Milk: milk collection system and pricing policies, https://ecourses online.icar.gov.in/mod/page/view.php?i $\mathrm{d}=6110$.

Pawar, D.B. and Pawar, B.R. 2010. Economics of milk production in different dairy enterprises in Maharashtra, International Journal of Commerce and Business Management; 3(2): 216-219.

Punjrath, J.S. 1989.India's all women dairy cooperatives, Review of International Cooperation, 82 (2): 31-38.

Rais et al., 2007. shodhganga.inflibnet.ac.in. Ramananda, M.S., and Mahendra, Kumar, S. 2010. Dairy Co-operatives: A stimulant for rural women", Indian Co-operative
Review, National Co-operative Union of India, New Delhi, 47 (4): 293-98.

Sardana 1988. shodhganga.inflibnet.ac.in.

Singh et al., 2012. An economic analysis of milk production in Bihar, Indian Journal of Animal Sciences; 82(10): 12331237.

Singh, M. and Joshi, A.S. 2008. Economic analysis of crop production and dairy farming on marginal and small farmers in Punjab. Agricultural Economics Research Review, 21(2): 30.

Thakur, D.S., Moorti, T.V., Saini, A.S. and Oberoi, R.C. 1989. Dairying for socioeconomic change in hills - A study of problems and possibilities of modernizing dairy industry for milk production enhancement in Himachal Pradesh. Mimeo, ISAE: 359.

\section{How to cite this article:}

Rakesh Kumar and Rahul Kumar. 2018. Socio-Economic Up-Liftment through Milk Production in Bihar, India. Int.J.Curr.Microbiol.App.Sci. 7(05): 1027-1034. doi: https://doi.org/10.20546/ijcmas.2018.705.127 